\section{De la crónica extensionista a la reflexión integral de la universidad}

Contino, P.y Daneri, M. (Comps.) (2016).

Rosario, Argentina: UNR Editora.

321 páginas. Disponible en versión digital.

Reseñado por Néstor Cecchi

Universidad Nacional de Mar del Plata, Argentina.

nestorcecchi@gmail.com

Las referentes de la Secretaría de Extensión y Vinculación de la Facultad de Ciencia Política y Relaciones Internacionales de la Universidad Nacional de Rosario publicaron hacia finales del año 2016 el libro Cartografías del Territorio. De la crónica extensionista a la reflexión integral de la universidad.

Diversas preguntas guían este trabajo y motivan la búsqueda reflexiva de aquellas intervenciones territoriales que se enmarcan en diferentes convocatorias institucionales en el campo de la extensión en el período comprendido entre los años 2008-2016. En ese sentido, aparecen cuatro prólogos y 22 artículos que, en términos teórico-metodológicos, componen esta publicación coral que recupera las voces de docentes, estudiantes y autoridades. Cada uno de ellos, con la singularidad que lo convierte en un proyecto social de carácter único, pero todos inspirados en el compromiso público y con la convicción de que la educación es un derecho humano fundamental. Desde ese lugar, emerge la interrelación de la universidad con la comunidad que le da sentido, manifestándose en la interdependencia conceptual entre pertinencia, calidad y autonomía.

El libro señala la imperiosa necesidad de que la universidad avance hacia la democratización real del conocimiento, de modo tal que aporte efectivamente a la construcción de sociedades más justas y equitativas. Sin duda este desafío no se consigue desde una función aislada sino desde la base estructural del sistema universitario. En palabras de las autoras:

«la extensión deja de ser un acto perimetral, voluntarioso o políticamente correcto, para transformarse en la pericia o competencia de un nuevo profesional preparado y comprometido para analizar, intervenir e innovar en las necesidades del territorio, ya no como sujeto académico fijo, sino en un vínculo con las múltiples formas de la vida".

En consecuencia, el libro enfatiza desde el prólogo, categorías analíticas que permiten pensar el tríptico misional docencia, extensión e investigación en forma convergente.

"Si el aula se vuelve porosa, flexible, se abre en términos literales y simbólicos, entablando diversas redes conversacionales con su comunidad de referencia, habrá posibilidad de cambios en las percepciones y representaciones de todos los actores
A 100 años de la Reforma Universitaria de 1918 /

Reseña de libros

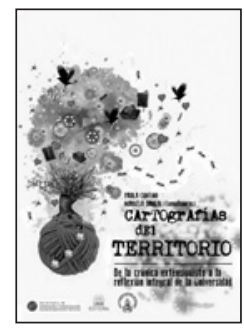

involucrados. (...) Esta tarea implica, también, la redefinición de la noción tradicional del aula. La construcción del concepto teórico-práctico de caula social, es decir un espacio permeable, constituido en las geografías del territorio y en la praxis de la interrogación".

En definitiva, este trabajo despliega algunas líneas que acompañan el debate y la reflexión hacia el interior de cada institución educativa, de manera que se conviertan en actores comprometidos con la trama social de su tiempo. 